Williams, G. R. (1957). J. gen. Microbiol. 16, 16-21

\title{
Haemolytic Material from Aerobic Sporing Bacilli
}

\author{
By G. R. WILLIAMS* \\ Sir William Dunn School of Pathology, University of Oxford
}

SUMMARY : Material from a strain of Bacillus subtilis which causes haemolysis was investigated. A fraction possessing the solubility properties of an organic acid appeared to be responsible for the haemolytic activity of the organism, but in the culture filtrate this material was associated with protein which modified its solubility properties considerably. Similar material was found in the culture filtrates of other haemolytic aerobic sporing bacilli.

Many members of the genus Bacillus are capable of causing haemolysis (Guillaumie, 1950). It is known that some species produce lecithinase (McGaughey \& Chu, 1948) and the haemolytic activity of these species may be accounted for in part, or completely, by their production of this enzyme (Chu, 1949). Production of lecithinase in this genus is, however, apparently confined to B. anthracis, B. mycoides and B. cereus (McGaughey \& Chu, 1948), and it seemed that an investigation of the haemolytic activities of those members of the group which do not elaborate lecithinase might be of interest. Büsing (1950) examined the haemolytic activity of a strain of $B$. subtilis and concluded that it was due to an esterase, but he did not in fact demonstrate such enzymic activity in his culture filtrates.

\section{METHODS}

Bacteria were grown in liquid media either in modified Monod T-tubes (van Heyningen \& Gladstone, 1953) or in whirling flasks (Mitchell, 1949). Each litre of medium contained the following constituents: $2.0 \mathrm{~g}$. $\mathrm{NaNO}_{3} ; 0.5 \mathrm{~g} . \mathrm{KCl}$; 1.0 g. $\mathrm{K}_{2} \mathrm{HPO}_{4} ; 0.5 \mathrm{~g} . \mathrm{MgCl}_{2} \cdot 6 \mathrm{H}_{2} \mathrm{O} ; 0.02 \mathrm{~g} . \mathrm{FeSO}_{4} \cdot 7 \mathrm{H}_{2} \mathrm{O} ; 40 \mathrm{ml}$. corn steep liquor diffusate; $12 \cdot 5 \mathrm{~g}$. glucose; $2 \cdot 5 \mathrm{~g}$. asparagine.

Production of haemolysin was tested for on plates of agar containing $\mathbf{0 . 5} \%(\mathrm{v} / \mathrm{v})$ of four-times-washed red blood cells of various species. The egg-yolk turbidity test for lecithinase activity was carried out according to McGaughey \& Chu (1948). Haemolysis was measured either visually by observing the time necessary after addition of haemolytic material for a line on the far side of a $1 \mathrm{~cm}$. test tube to become visible through the haemolysing suspensions of red cells, or by an electrochemical technique to be described elsewhere. This latter method could not be applied to the estimation of haemolytic material in the culture filtrates owing to interference by reducing substances in the media. Protein was determined by the biuret method according to Gornall, Bardawill \& David (1949). Ultraviolet absorption spectra were determined in a Beckman model DU spectrophotometer.

* Present address: Banting and Best Department of Medical Research, University of Toronto, Canada. 


\section{RESULTS}

Forty-three strains of aerobic spore-forming bacilli were screened for haemolytic activity against red blood cells of rabbit, horse, sheep and man; the results are summarized in Table 1 . The fourteen most active strains (as judged by the extent of the haemolysis zones) were selected, grown for $24 \mathrm{hr}$. in T-tubes, and their culture filtrates tested for activity against human red blood cells and

Table 1. Distribution of haemolytic activity amongst the strains of Bacillus spp. tested

\begin{tabular}{|c|c|c|c|c|c|}
\hline & & & Red b] & $\mathrm{d}$ cells & \\
\hline & & Rabbit & Horse & Sheep & Man \\
\hline & $\begin{array}{l}\text { No. of } \\
\text { strains }\end{array}$ & No. & $\begin{array}{l}\text { f strains } \\
\text { aemolyt }\end{array}$ & $\begin{array}{l}\text { ving po } \\
\text { reaction }\end{array}$ & \\
\hline B. subtilis & 6 & 2 & 2 & 1 & 2 \\
\hline B. pumilus & 6 & 6 & 5 & 3 & 4 \\
\hline B. licheniformis & 6 & 6 & $\mathbf{1}$ & $\mathbf{0}$ & 1 \\
\hline B. cereus & $\gamma$ & 7 & 7 & 7 & 7 \\
\hline B. mycoides & $\mathbf{3}$ & 1 & $\mathbf{2}$ & $\mathbf{0}$ & $\mathbf{0}$ \\
\hline B. megaterium & 4 & 0 & 0 & 0 & $\mathbf{0}$ \\
\hline B. carotarum & $\mathbf{3}$ & $\mathbf{0}$ & $\mathbf{0}$ & $\mathbf{0}$ & $\mathbf{0}$ \\
\hline B. brevis & $\mathbf{5}$ & 3 & 2 & 0 & 0 \\
\hline B. circulans & 2 & 1 & 1 & 1 & 1 \\
\hline B. alvei & 1 & 1 & 1 & 0 & 1 \\
\hline Total & 43 & $2 \gamma$ & 21 & 12 & 16 \\
\hline
\end{tabular}

for egg-yolk reaction. On the basis of these tests, ten strains were chosen as strongly haemolytic and unreactive in the lecithinase test and therefore useful for further investigation. One strain of Bacillus subtilis (strain 14) was particularly active and it was decided to attempt the isolation of the haemolytic material produced by this organism.

Partial purification of the haemolytic protein of Bacillus subtilis strain 14

The haemolytic material produced by Bacillus subtilis strain 14 was quantitatively precipitated by $4 / 5$ saturation with ammonium sulphate. The precipitate from each litre of filtrate was dissolved in $200 \mathrm{ml} .0 .05 \mathrm{M}-\mathrm{Na}_{2} \mathrm{HPO}_{4}$, a slight insoluble residue being removed by centrifugation. The solution was adjusted to $\mathrm{pH} 4.5$ and a precipitate appeared. This was centrifuged off and the clear supernatant fluid was found to be free from haemolytic activity. The precipitate was dissolved in the least possible volume of $0.15 \mathrm{~m}$-trishydroxymethylaminomethane ('tris') at $\mathrm{pH} \mathrm{8 \cdot 0.} \mathrm{The} \mathrm{'tris'} \mathrm{solution} \mathrm{was} \mathrm{made} 10 \mathrm{~mm}$ with respect to $\mathrm{Zn}^{++}$by the addition of $0 \cdot 12 \mathrm{M}-\mathrm{ZnCl}_{2}$ and the resultant inactive precipitate centrifuged down. This $\mathrm{Zn}^{++}$precipitation brought about a twofold increase in the haemolytic activity per mg. protein in the supernatant fluid. The supernatant fluid was then made $20 \mathrm{~mm}$ with respect to ethylenediamine tetra-acetate (EDTA) and $\mathbf{3}$ vol. of saturated ammonium sulphate were added. The resultant precipitate was dissolved in $\mathbf{0 . 1 5}$ $\mathrm{M}-\mathrm{Na}_{2} \mathrm{HPO}_{4}$. This preparation was only about 6-7 times more active per $\mathrm{mg}$. 
protein than the original culture filtrate and was heterogeneous by zone electrophoresis on paper. However, further purification of this material was not attempted after the demonstration that the haemolytic material produced by this strain could be obtained in another form possessing very different solubility properties (see below).

\section{The alcohol-soluble haemolytic material}

The name tyrothricin was given by Hotchkiss \& Dubos (1940) to the crude mixture of polypeptides (gramicidin and tyrocidine) from Bacillus brevis (strain B.G.) because of the similarity of this material to the bacteriostatic agent liberated by certain cultures of ' $T$ yrothrix' (Rosenthal, 1925) which were later identified as strains of $B$. subtilis (Smith, 1941). It appeared possible that the haemolytic activity of the $B$. subtilis 14 culture filtrates might be due to surface-active polypeptides similar to tyrothricin (Dubos \& Hotchkiss, 1941). The culture filtrates were therefore processed according to Dubos \& Cattaneo (1939). Early experiments showed that haemolytic material could be obtained in this manner, but the differences between the properties of the resultant product and those of tyrothricin suggested various modifications. The method finally used was the following: 1.51 . of culture filtrate was $80 \%$ saturated with ammonium sulphate and the precipitate suspended for 2-3 hr. at room temperature in $75 \mathrm{ml}$. acetone, acidified with $0.2 \mathrm{ml}$. of $5 \mathrm{~N}$-hydrochloric acid. The inactive protein precipitate was filtered off and the acetone solution evaporated at $45^{\circ}$ under reduced pressure to $c .10 \mathrm{ml}$. This solution was then added to 5 vol. of water, the $\mathrm{pH}$ value adjusted to $\mathbf{3 . 5}$ and the resulting precipitate dissolved in the minimum volume of 'tris' buffer $(\mathrm{pH} \mathrm{8 \cdot 0)}$. The material so prepared was thus distinguished from tyrothricin by its solubility in alkaline aqueous solutions. A further distinction was provided by the fact that, when the $\mathrm{pH}$ value of the 'tris' solution was lowered to $6 \cdot 0$, the haemolytic material could be extracted by ether, from which it could be re-extracted by alkaline aqueous buffer. It could be precipitated from alkaline aqueous solution by acidification or by adding alkaline earth cations, a characteristic which distinguished this material from the bacilipins (Newton, 1949). The bariumprecipitated material was soluble in EDTA solutions or in ethanol. The acidprecipitated material was soluble in methanol, ethanol, $n$-butanol, acetone, diethyl ether and benzene, but not in light petroleum. The material absorbed in the long wavelength ultraviolet with a maximum at $275 \mathrm{~m} \mu$. (Fig. 1) and from this characteristic and its solubility properties is referred to as ' 275 -acid'. The nature and the degree of purity of this preparation of '275-acid' are unknown; it gives a slowly developing biuret reaction and a weak ninhydrin reaction ( $5 \mathrm{mg}$. ' 275 -acid' $=5 \mu \mathrm{g}$. leucine), and its nitrogen content is $c .1 \%$ (Kjeldahl N/dry wt.).

\section{Relationship of the two forms of the haemolytic material}

When the haemolytic protein fraction, at any stage of purification, is subjected to the procedure outlined in the previous section ' 275 -acid' is obtained. Table 2 shows that as the purification proceeded the ratio of 
'275-acid' to total u.v.-absorbing material greatly increased and it therefore appears that the haemolytic activity of the protein fractions is attributable to their content of ' 275 -acid', the solubility properties of which must be greatly modified by its association with protein.

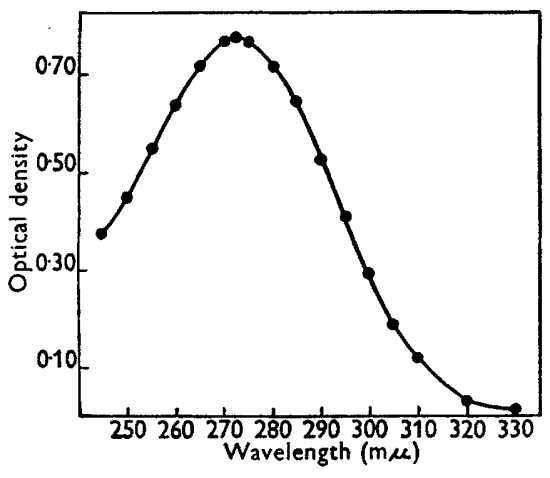

Fig. 1

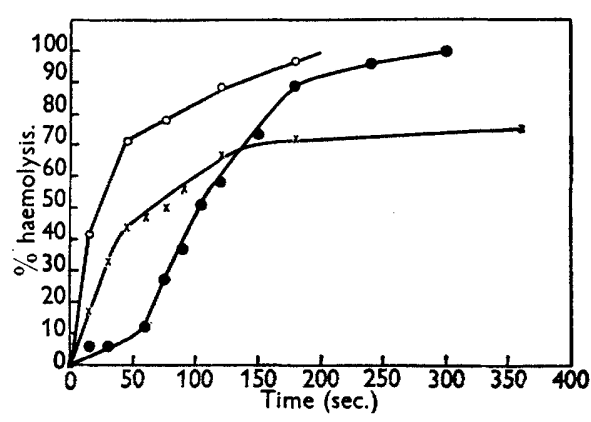

Fig. 2

Fig. 1. Absorption spectra of the alcohol-soluble haemolytic material. The $E_{1 \mathrm{~cm} .}^{1 \% \text { at }} 270 \mathrm{~m} \mu$. is $\mathbf{1} \cdot 2$.

Fig. 2. Kinetics of haemolysis by the '275-acid' preparation. $O-0$, '275-acid'; $0.86 \mathrm{mg} . / \mathrm{ml}$. $\times \longrightarrow \times$, ' 275 -acid'; $0.35 \mathrm{mg} . / \mathrm{ml}$. @- saponin; $0.07 \mathrm{mg} . / \mathrm{ml}$.

Table 2. The '275-acid' content of the protein fraction during purification

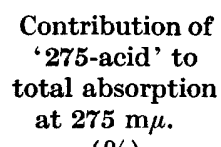

Contribution of

'275-acid' to

total absorption

at $275 \mathrm{~m} \mu$.

Fraction

Ammonium sulphate ppt.

pH 4.5 precipitate

Zinc-soluble
$(\%)$

13

32

79

\section{Biological distribution of ' 275 -acid'}

Culture filtrates from seven other haemolytic strains of aerobic sporeforming bacilli were examined for alcohol-soluble, acid-insoluble material absorbing at $270 \mathrm{~m} \mu$. The degree of haemolysis was measured by the visual method and as the relationship between dilution and rate of haemolysis appeared to be exponential under these conditions and the method itself is only semi-quantitative, it is not possible to give an accurate account of the haemolytic activities of these filtrates in terms of their content of ' 275 -acid'. However, Table 3 clearly suggests that the haemolytic activity of the culture filtrates of Bacillus lichenformis 64 and $B$. circulans 82 cannot be attributed to the ' 275 -acid' content of the filtrates, and that in other cases there may be other haemolytic material present. This question obviously requires much further examination. 


\section{Kinetics of haemolysis by '275-acid'}

Fig. 2 shows the haemolysis progress curves given by the preparation of '275-acid' and washed human red blood cells. The S-shaped curve given by many haemolysins was not obtained and the shape of the curve resembles that obtained with tyrocidine (Bernheimer, 1947). However, the initial rate of haemolysis appears to be directly proportional to ' 275 -acid' concentration, in which respect it differs from tyrocidine. It should, however, be observed that

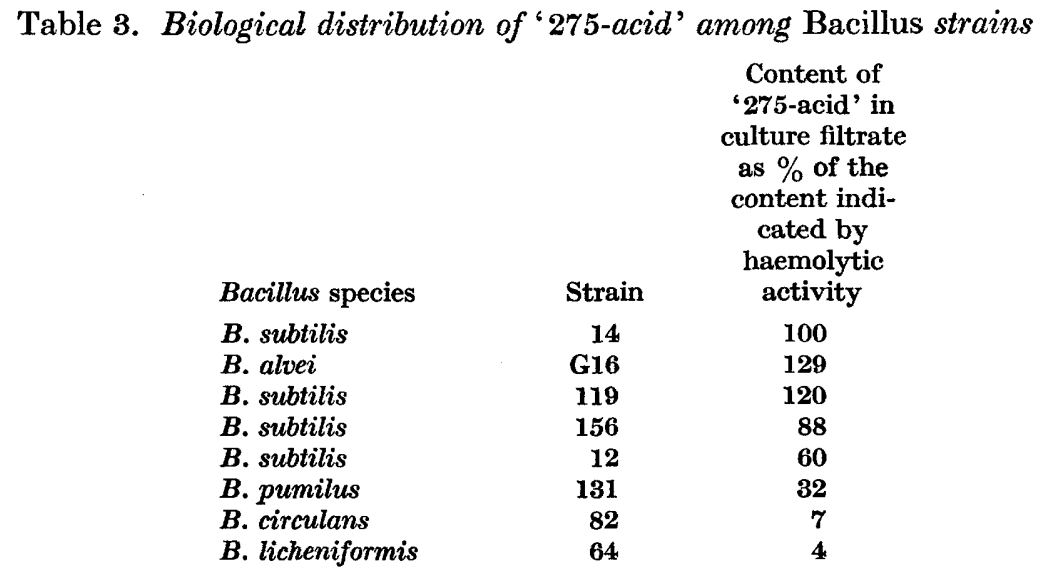

under the conditions of the visual assay the relationship between haemolysis rate and dilution appeared to be exponential. In this case the time observed is the time to reach an unknown but presumably high percentage of haemolysis and this method therefore tends to measure the slow phase of the haemolysis curves of Fig. 2, a distribution which may perhaps account for the different mathematical relationship. It will be observed that the preparation of ' 275 acid' in its present state of purity has a very low activity compared with, say, saponin.

\section{DISCUSSION}

The haemolytic activity of the protein fraction obtained from Bacillus subtilis strain 14 may be attributed to the acetone-soluble, water-insoluble ' 275 -acid' that can be derived from this fraction. At first sight the association between the acid and the protein might appear to be of some biological importance by providing an example of a quasi-toxic protein the activity of which may be attributed to a 'prosthetic group'. van Heyningen (1950) commented on the possibility that the oxygen-labile haemolysins may contain a surface-active prosthetic group with haemolytic activity. However, the demonstration that the bulk of the ultraviolet absorption of the active protein fraction is accounted

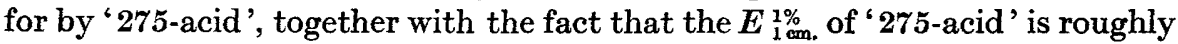
one-tenth that of most proteins, suggests that, in fact, this fraction must be made up of $c .1 \%$ of protein and $99 \%$ of 'prosthetic group' on a weight for weight basis. This being so, it is doubtful whether this association is specific and 
it may be that a non-specific 'solubilization' of ' 275 -acid' should be invoked. Tyrothricin was originally obtained in a protein-bound form (Dubos, 1939) and in this case also the nature and specificity of the association is unknown (Hotchkiss, 1944).

This problem was suggested to me by Dr W. E. van Heyningen, and I am greatly indebted to him for many helpful discussions. The work was carried out under a Medical Research Council Grant for assistance to him. I gratefully acknowledge the competent technical assistance of Miss P. Rowlands.

\section{REFERENCES}

Bernheimer, A. W. (1947). Comparative kinetics of hemolysis induced by bacterial and other hemolysins. J. gen. Physiol. 30, 337.

Büsıng, K. H. (1950). Subtilis hemolysin. Arch. Hyg., Berl. 133, 69.

CHU, H. P. (1949). The lecithinase of Bacillus cereus and its comparison with Clostridium welchii $\alpha$-toxin. J. gen. Microbiol. 3, 255.

Duвos, R. J. (1939). Studies on a bactericidal agent extracted from a soil bacillus. I. Preparation of the agent. Its activity in vitro. J. exp. Med. 70, 1.

Dubos, R. J. \& Cattaneo, C. (1939). Studies on a bactericidal agent extracted from a soil bacillus. III. Preparation and activity of a protein-free fraction. J. exp. Med. 70, 249.

Duвos, R. J. \& Нотснкiss, R. D. (1941). The production of bactericidal substances by aerobic sporulating bacilli. J. exp. Med. 73, 629 .

Gonnall, A. G., Bardawill, C. J. \& David, M. M. (1949). Determination of serum proteins by means of the biuret reaction. J. biol. Chem. 177, 751 .

Guillaumie, M. (1950). Hémolysines bactériennes et antihémolysines. Ann. Inst. Pasteur, 79, 661.

Hotchkrss, R. D. (1944). Gramicidin, tyrocidine and tyrothricin. In NoRD, F. F. \& Werkman, C. H., Eds. Advanc. Enzymol. 4, 153.

Hотснкіss, R. D. \& Dubos, R. J. (1940). Bactericidal fractions from an aerobic sporulating bacillus. J. biol. Chem. 136, 803.

McGaughey, C. A. \& Chu, H. P. (1948). The egg-yolk reaction of aerobic sporing bacilli. J. gen. Microbiol. $2,334$.

Mrtcheld, P. (1949). A new technique for stirred aerated culture. Nature, Lond. 164, 846.

Newton, G. G. F. (1949). Antibiotics from a strain of B. subtilis: bacilipin A and B and bacilysin. Brit. J. exp. Path. 30, 306.

Rosenthal, L. (1925). Microbes bactériolytiques (lysobactéries). C.R. Soc. Biol., Paris, 92, 78.

Smrth, N. (1941). Reported in footnote 1 of Dubos \& Hotchkiss (1941).

van Heyningen, W. E. (1950). Bacterial Toxins, p. 59. Oxford: Blackwell.

van Heyningen, W. E. \& Gladstone, G. P. (1953). The neurotoxin of Shigella shigae. 3. The effect of iron on production of the toxin. Brit. J. exp. Path. 34, 221.

(Received 19 June 1956) 